\title{
Rapeseed and canola meal as protein sources in starter diets for calves: current knowledge and directions of future studies
}

\author{
Pawel GÓRKA ${ }^{1, a, \bowtie}$, Gregory Brent PENNER ${ }^{2, b}$ \\ ${ }^{1}$ University of Agriculture in Krakow, Department of Animal Nutrition and Biotechnology, and Fisheries, Krakow, Poland; \\ ${ }^{2}$ University of Saskatchewan, Department of Animal and Poultry Science, Saskatoon, Canada. \\ aORCID: 0000-0002-4278-0493; bORCID: 0000-0002-6396-2130

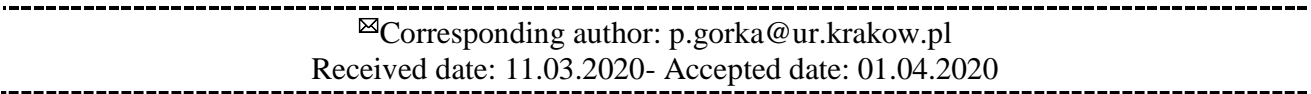

\begin{abstract}
Rapeseed and canola meal are not commonly used in starter diets for calves due to concerns over palatability and digestibility of the feed. The aim of this paper was to briefly summarize our knowledge on the effects of rapeseed and canola meal use in starter diets for calves, with particular emphasis on the period before and shortly after weaning, and the impact on feed intake, nutrient digestibility, body weight gain, and feed efficiency of calves. Possible strategies allowing for increased inclusion of rapeseed and canola meal use in calves' nutrition were also suggested and briefly discussed.
\end{abstract}

Keywords: Alternative protein, calf, canola meal, rapeseed meal, starter feed

\section{Introduction}

Meals, expellers, or cakes derived from both rapeseed and canola, are widely used protein sources in diets for dairy cows and beef cattle $(20,31,35)$ but not in diets for newborn calves. This is mostly due to the concerns over palatability (32) and digestibility $(24,37)$ of calf starters containing by-products arising from rapeseed and canola crushing. However, negative impacts of feeding rapeseed and canola meal to calves were shown in some $(9,14)$ but not all studies $(10,39)$, and this impact depended on many factors [e.g., content of glucosinolates in the meal or level of meal inclusion in the feed $(9,37)]$, indicating that by-products of rapeseed and canola processing have potential to be effectively used in diets for newborn calves.

The aim of this paper was to summarize knowledge on the effect of rapeseed and canola meal use in starter diets for calves. Although various other by-products of rapeseed and canola crushing can be used in animal nutrition, to the authors knowledge, only studies investigating impact of feeding rapeseed and canola meal to newborn calves are available in the literature. Thus, the scope of this paper will be limited to the use of rapeseed and canola meal in diets for calves. Furthermore, effects of rapeseed and canola meal usage in starter diets for calves will be compared with soybean meal usage, a source of protein considered as the 'gold standard' in calf starters, and also included in the experimental designs of nearly all studies available in the literature. Therefore, when a positive or negative impact of rapeseed and canola meal use in diets for calves was discussed in this review, this was in comparison with soybean meal use. Lastly, potential strategies allowing for increased efficiency of rapeseed and canola meal use in diets for calves were suggested and briefly discussed.

\section{Basic information}

For purpose of the current review, ten papers available in peer-reviewed journals were reviewed and this list was extended by two abstracts presented at an international symposia and results of one diploma thesis. Methodology of those studies and their results are summarized in Table 1. Furthermore, for the purposes of the current review, the origin of the meal used in the study (i.e. rapeseed or canola) was clearly distinguished and in the case of rapeseed meal use, the concentration of glucosinolates was specified (low or high; if reported in the paper or report). In such a case, high glucosinolate content was considered when the concentration exceeded $25 \mu \mathrm{mol} / \mathrm{g}(28)$. 


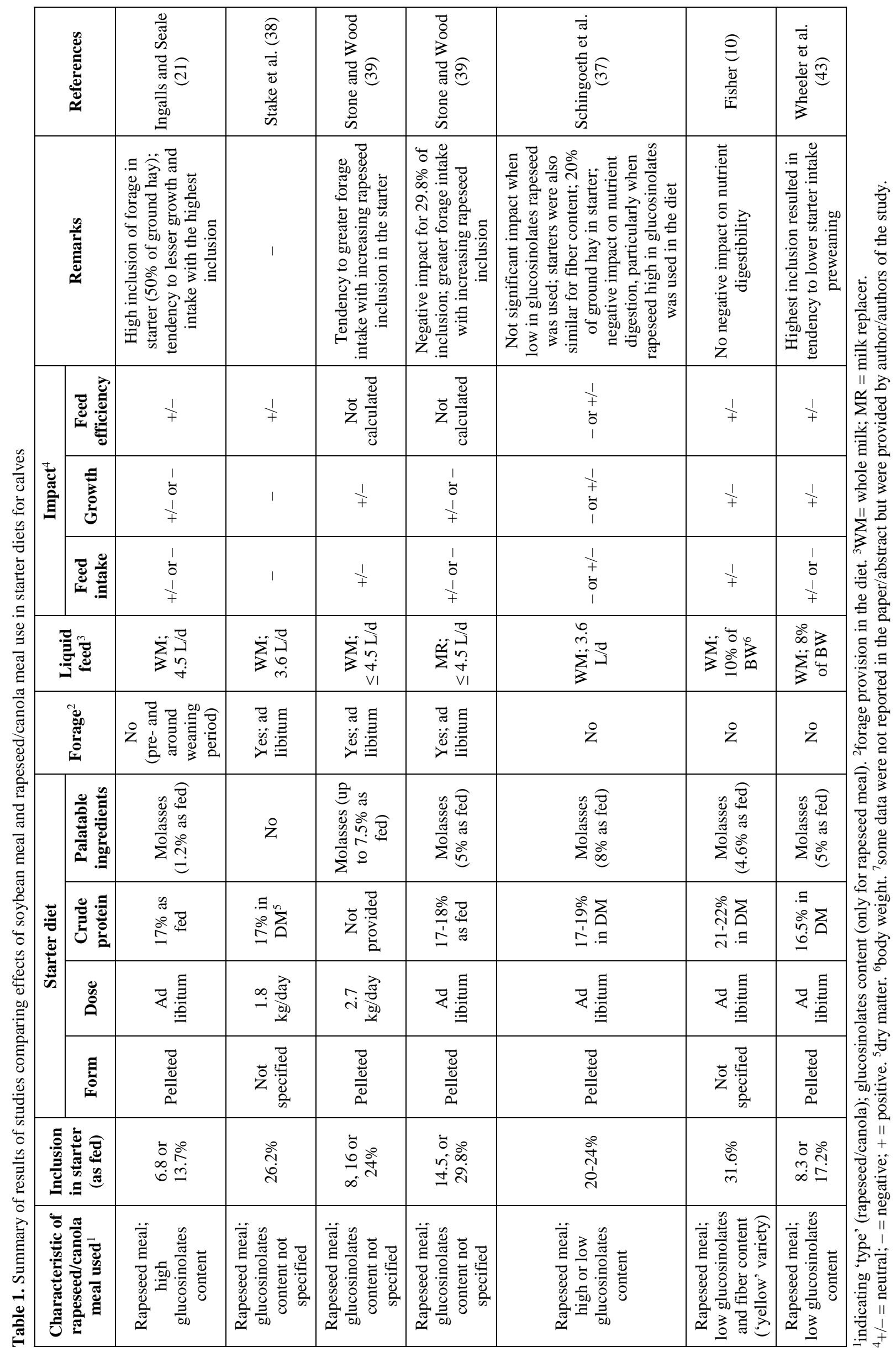




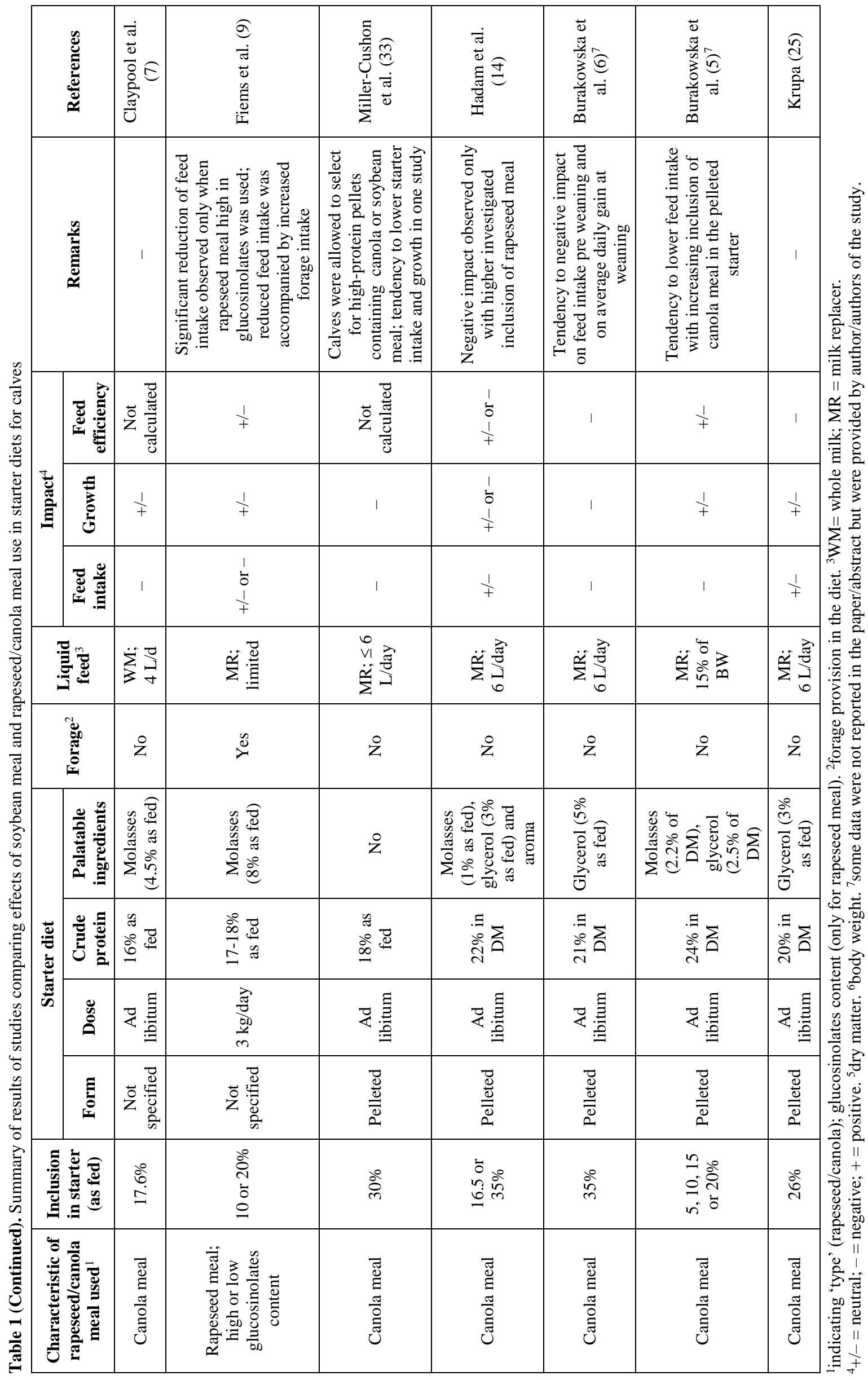


Rapeseed meal that has been derived from doublezero varieties of rapeseed or canola meal are currently used in animal nutrition. The use of double-zero rapeseed varieties and canola varieties indicates that the meals contain less than $30 \mu \mathrm{mol}$ of glucosinolates/g and less than $2 \%$ of erucic acid in the oil fraction (36). Furthermore, the terms double-zero rapeseed and canola are used synonymously. In fact, the term canola was coined to identify varieties of rapeseed low in glucosinolates and erucic acid (3), and thus is commonly used to identify double-zero rapeseed (27). Furthermore, varieties of rapeseed that could be classified as canola are, in some instances, reported as double-zero rapeseed or rapeseed low in glucosinolates (43). Therefore, it can be speculated that distinction between canola meal and rapeseed meal low in glucosinolates and erucic acid could be avoided. However, the concentration of glucosinolates (and also erucic acid) in rapeseed meal has not been specified in all studies and it cannot be excluded that some differences between canola meal and rapeseed meal derived from double-zero plants may occur. For example, available data suggest that meal derived from double-zero rapeseed contains less protein, more fiber, and more glucosinolates (and thus possibly other antinutritional factors) compared to canola meal $(16,41)$; however, those differences are likely a result of varieties of rapeseed and canola that were used in particular studies, possible greater variation of chemical composition for double-zero rapeseed than canola, or other factors $(26,30)$. Thus, for purposes of the current review, the term rapeseed/canola (RC) meal will be used to generically discuss double-zero rapeseed and canola meal collectively, but reference to specific study will be made to clarify the origin of the meal evaluated (rapeseed or canola). Furthermore, as already mentioned, in the case of rapeseed meal high in glucosinolates use in the study, this fact will be clearly indicated (if this information is provided by the author/authors of the study) to distinguish between past and more recent rapeseed meals.

Rapeseed/canola meal contains less crude protein (38.1 vs. $55.2 \%$; dry matter basis) and lysine (5.3 vs. 6.2 $\mathrm{g} / 16 \mathrm{~g} \mathrm{~N}$ ), but more methionine ( 2 vs. $1.4 \mathrm{~g} / 16 \mathrm{~g} / \mathrm{N}$ ) than soybean (SB) meal (Table 2). However, on average, RC meal also contains over three times more neutral detergent fiber (31.6 vs. 10.5\%), three times more acid detergent fiber (20.7 vs. $5.7 \%$ ), and over twenty times more lignin ( $9.7 \%$ vs. 0.4 in dry matter) than SB meal. The latter one is the most apparent and one of the most important differences between RC meal and SB meal due to the substantial negative impact of lignin content in the feed on nutrient digestion (42). Therefore, when impact of RC meal and SB meal use in diets for calves is compared, it may vary greatly depending on the strategy of $\mathrm{RC}$ inclusion in the diet. Specifically, studies that focus on simply replacing SB meal in the feed with RC meal may yield a differing result than studies that utilize those ingredients but try to minimize changes in dietary composition (e.g., crude protein, fiber, and starch all balanced to be similar).

Table 2. Chemical composition of soybean and rapeseed/canola meal [adopted from Heuzé et al. (15) and Heuzé et al. (16)]

\begin{tabular}{|c|c|c|}
\hline Ingredient & Soybean meal & $\begin{array}{c}\text { Rapeseed/canola } \\
\text { meal }\end{array}$ \\
\hline Dry matter (DM), g & 88.0 & 89.0 \\
\hline Crude protein, \% DM & 55.2 & 38.1 \\
\hline Crude fiber, \% DM & 4.4 & 14.3 \\
\hline $\mathrm{NDF}^{1}, \% \mathrm{DM}$ & 10.5 & 31.6 \\
\hline $\mathrm{ADF}^{2}, \% \mathrm{DM}$ & 5.7 & 20.7 \\
\hline Lignin, \% DM & 0.4 & 9.7 \\
\hline Ether extract, \% DM & 1.7 & 2.4 \\
\hline Ash, \% DM & 7.3 & 7.6 \\
\hline Starch, \% DM & 1.1 & 1.6 \\
\hline Total sugars, \% DM & 10.8 & 10.5 \\
\hline \multicolumn{3}{|l|}{ Amino acid, g/16 g N } \\
\hline Alanine & 4.3 & 4.3 \\
\hline Argninine & 7.3 & 5.8 \\
\hline Aspartic acid & 11.3 & 7.1 \\
\hline Cysteine & 1.6 & 2.4 \\
\hline Glutamic acid & 17.9 & 17 \\
\hline Glycine & 4.2 & 5.0 \\
\hline Histidine & 2.7 & 2.7 \\
\hline Isoleucine & 4.6 & 4.0 \\
\hline Leucine & 7.7 & 6.8 \\
\hline Lysine & 6.2 & 5.3 \\
\hline Methionine & 1.4 & 2.0 \\
\hline Methionine+cystine & 3.0 & 4.4 \\
\hline Phenylalanine & 5.1 & 3.9 \\
\hline Proline & 5.0 & 6.0 \\
\hline Serine & 4.6 & 4.4 \\
\hline Threonine & 3.8 & 4.3 \\
\hline Tryptophan & 1.4 & 1.2 \\
\hline Tyrosine & 3.5 & 2.8 \\
\hline Valine & 4.8 & 5.1 \\
\hline
\end{tabular}

${ }^{1}$ neutral detergent fiber.

${ }^{2}$ acid detergent fiber. 


\section{Impact on feed intake}

A negative effect of $\mathrm{RC}$ meal use in calf starter on starter intake or at least a tendency for a reduction has been shown in numerous studies $(5-7,9,33,37-39,43)$. From the available literature, it is clear that such an impact is expected mostly when rapeseed meal high in glucosinolates is used in the starter feed $(9,22,37)$, inclusion of RC meal in the starter exceeds 20 to $25 \%$ of the starter $(6,38-39)$, or when RC meal is used to replace over 50 to $60 \%$ of SB protein (5; Table 1).

As already mentioned, not only absolute inclusion of $\mathrm{RC}$ meal in the starter, but also amount of SB protein that is replaced may have a significant impact on starter intake. For example, when inclusion rate of RC meal in the starter was less than 20 to $25 \%$ but it replaced over $50 \%$ of SB meal protein within the starter, starter intake was negatively affected (5). Furthermore, a reduction in starter intake may be observed even when more complex formulations of calf starters are used that include other high-protein feeds (e.g., wheat bran or corn gluten meal). It should be noted that the other high-protein feeds reduce the overall dietary inclusion of RC meal to avoid inclusion rates greater than 20 to $25 \%$ of the starter but still allow for substantial replacement of SB protein (5). Thus, still observed negative impact on feed intake (5) effect may be attributed to the fact that other high-protein feeds may not be as acceptable to calves as SB meal, or that interactions between various high-protein feeds used in starter mixtures occurs, which lead to reduced intake.

Reduced feed intake by calves offered starter diets with RC meal is, in general, attributed to low palatability of RC meal. Indisputably, both past as well as more recent studies have provided clear evidence that RC meal is less palatable than other feeds, at least for calves. This includes lower palatability of RC meal when compared to SB meal. Specifically, Stone and Wood (39) observed that calves sorted against rapeseed meal (content of glucosinolates not specified) when starter in meal form was provided to calves, and Miller-Cushon et al. (32) and Miller-Cushon et al. (33) showed in a short-term preference test as well as a medium-term study that calves preferred SB meal over canola meal and selected against pellets containing canola meal even when were familiarized with this feed. Therefore, pelleting of all components of the starter mixture in order to limit feed sorting (39), as well as to prevent consumption of an unbalanced protein to energy ratio (33) could be used to at least partially prevent reduced feed intake and other potential negative consequences (i.e. reduced feed efficiency) when RC meal is included in calf starters. However, high inclusion rates of RC meal are still likely to result in reduced starter intake (33).

In a recent report, inclusion of glycerol (sweet flavor) increased intake of a pelleted starter containing canola meal as the main source of protein [5\% of glycerol in dry matter; (4)], which suggests high palatability of glycerol for calves but also supports the unpalatable taste of RC meal, as suggested by Miller-Cushon et al. (32) and Miller-Cushon et al. (33). Similarly, molasses and feed flavors were reported to be, to some extent, effective in masking an unpleasant taste of rapeseed meal in weaned calves (37). Results of those reports may suggest that low palatability of calf starters containing RC meal could be even underestimated because in the majority of studies conducted, molasses or glycerol (both sweet) were important components of experimental feeds and their inclusion oftentimes was greater than $5 \%$ of the starter dry matter (Table 1). Sweet taste seems to have a positive value in cattle (11) and when the aforementioned sweet feeds were not components of calf starter, an apparent negative impact on feed intake was observed (38). Thus, use of palatable compounds or commercial feed flavors in calf starters can be a valuable and effective strategy allowing for increased inclusion of RC meal use in diets for calves, in combination with pelleting to prevent sorting against unpalatable components (39).

Low palatability of RC meal is thought to be a result of breakdown products arising from glucosinolates (i.e. isothiocyanate and thiocyanate) in the meal which are pungent, as well as sinapine and tannins which are bitter $(8,41)$. Despite presence of various unpalatable compounds in RC meal, reduced feed intake in calves fed starters with RC meal was largely attributed to glucosinolates content $(9,37)$. Based on a review of available studies, it was also suggested that feed intake by calves is not reduced when levels of glucosinolates in the diet do not exceed 5.5 to $7.7 \mu \mathrm{mol} / \mathrm{g}$ but may be depressed when concentrations range from 10.5 to $15.4 \mu \mathrm{mol} / \mathrm{g}$ (28). Because not all studies report the concentration of glucosinolates, for the purpose of aforementioned predictions, the authors assumed that high and low in glucosinolates rapeseed meal contained 90 and $25 \mu \mathrm{mol}$ glucosinolates/g of meal, respectively. Taking into account that the glucosinolate content in the currently used $\mathrm{RC}$ meal rather does not exceed $12-13 \mu \mathrm{mol} / \mathrm{g}$ of meal (16, $30)$ and that still negative impacts of its use in calf starters on starter intake can be detected (5-6), it is unlikely that glucosinolates are mostly responsible for this negative impact, even when RC meal fully replaces SB meal in the starter. As an example, assuming $\mathrm{RC}$ meal inclusion accounts for up to $30 \%$ of the total starter, glucosinolate content in the feed should be still less than $4 \mu \mathrm{mol} / \mathrm{g}$. Therefore, content of other unpalatable compounds or antinutritional factors are likely mostly responsible for lower intake of starters containing RC meal by calves.

The concentration of unpalatable compounds, excluding glucosinolates (i.e. sinapine, phytic acid, tannins), may differ substantially across differing sources 
of RC meal. While not thoroughly investigated, previous studies comparing variability in RC meal has highlighted substantial inter- and intra-plant variability for macronutrients $(26,30)$ and more detailed research has reported substantial intra-plant variability for ileal protein digestibility in pigs (1). While that research was conducted with swine, relevance of variability in intestinal digestibility is present for calves prior to weaning. Furthermore, in most of the past studies, the impact on very young calves (i.e. in first 3-4 weeks of age) was often not presented (i.e. data for the whole rearing period was only reported), and there are studies suggesting that after weaning starter intake may be even increased when it contains $\mathrm{RC}$ meal $(6,14)$. In consequence, a reduction of not only glucosinolates (or erucic acid), but also other antinutritional and unpalatable factors are necessary to increase value of RC meal for newborn calves. We have reported that when canola meal that was heat-treated at $100^{\circ} \mathrm{C}$ for $10 \mathrm{~min}$ was fed to calves, the heat-treatment process reduced starter intake (4) suggesting that heat damage of RC may also lead to reduced starter intake. Heat damage is expected to reduce ruminal degradability and excessive heat exposure may also reduce intestinal digestibility. The reduction for starter intake when using heat-treated canola meal further suggests that the process imposed by RC crushing plants may alter palatability of the canola meal. As such, for better interpretation of results of published studies, the content of glucosinolates and other antinutritional factors and unpalatable compounds should be reported along with processing conditions for the RC following oil extraction. Additionally, further studies should be conducted to define which antinutritional factors or unpalatable compounds present in RC meal impact calves the most.

It is worth emphasizing that in the majority of studies conducted, calves were fed very limited amounts of milk or milk replacer, and were oftentimes weaned relatively early ( $\approx 5$ weeks of age). Taking into account that the negative impact of RC meal on performance of calves is expected predominantly in first $3-4$ weeks of age $(6,14)$ and that greater intake of liquid feed delays solid feed intake by calves (23), feeding more milk or milk replacer to calves can limit potential negative consequences of feeding starter containing RC meal. Furthermore, forage provision seems to increase when starter with $\mathrm{RC}$ meal is fed to calves, which may compensate, at least partially, for lower starter intake $(9,39)$. Thus, the combination of feeding more liquid feed to calves and provision of forages (23), may be a strategy allowing for increasing inclusion of $\mathrm{RC}$ meal use in diets for calves without a substantial negative impact on feed efficiency. Also, delaying weaning until $\geq 8$ weeks of age, particularly when more milk or milk replacer is fed to calves, allows for more efficient solid feed digestion after weaning $(19,29)$, and thus may prevent potential negative impacts of $\mathrm{RC}$ meal feeding to calves at or after weaning, as reported in many studies $(5-6,9,37)$. However, the interaction between different milk or milk replacer feeding programs and composition of the starter feed is currently unknown, including the economic outcomes for producers.

\section{Impact on nutrient digestion}

Not many studies have investigated the impact of RC meal use in diets for calves on nutrient digestibility; however, in those that have, reductions in digestibility are generally observed $(24,37)$. Nevertheless, it is commonly accepted that RC meal use in diets for calves has a negative effect on nutrient digestion. The reduction in digestibility with RC meal inclusion is further supported based on studies conducted with sheep (9) or studies using calves that were fed at a maintenance level (44).

However, taking into account the presence of various antinutritional factors and relatively high fiber content in $\mathrm{RC}$ meal, the fact that its use in starter mixture has or at least may have a negative impact on nutrient digestibility in calves is rather not surprising. It should also be mentioned that the impact of RC meal use in feed for calves was investigated mostly postweaning when the gastrointestinal tract, including the rumen, small intestine, and pancreas is nearly fully developed (13). In consequence, for newborn calves (e.g., in first 3-4 weeks of age) with a developing gastrointestinal tract (and thus may not cope well with antinutritional factors and less digestible feeds), the efficiency of RC meal use may be especially limited, as suggested by results of some studies $(6,14)$.

Reduced intestinal protein digestion in calves when the starter contains RC meal is of critical concern $(24,37)$. However, limited intestinal availability of amino acids from canola meal was shown when its inclusion in solid feed was very high and accounted for $43 \%$ of dietary dry matter (24). On the other hand, when lower inclusion of rapeseed meal was used in a pelleted starter mixture (20 to $24 \%$ of the starter), the negative impact on protein digestion was observed primarily when rapeseed meal high in glucosinolates was used (37). Moreover, reduced protein digestion due to $\mathrm{RC}$ meal feeding was not detected in all studies, at least when feed intake was not restricted to a maintenance level and when rapeseed meal low in glucosinolates and fiber were used $(10,44)$. In more recent studies, a tendency for reduced nutrient digestion in calves was observed when canola meal fully replaced SB meal in a pelleted calf starter (Burakowska K., Penner G. B., Korytkowski Ł., Kowalski Z. M., Górka P., unpublished), but not when this replacement ranged from 0 to $60 \%$ of SB protein (5). As such, it seems that reduced digestion of protein may be an issue especially when RC meal inclusion in starter feed is high, or when the glucosinolate 
content in the meal is high; however, the latter should not occur with the double-zero rapeseed or canola varieties available.

It is quite clear that antinutritional factors present in $\mathrm{RC}$ meal, at least to some extent, contribute to the reduced nutrient digestion in calves. To support this suggestion, calf gastrointestinal tract function is known to be negatively affected by various antinutritional factors, such as glycinin and beta-conglycinin (34). Furthermore, the most apparent reduction in nutrient digestion was observed when rapeseed meal high in glucosinolates was used in calf starter (37). Nevertheless, the relatively high fiber content in RC meal likely also limits efficiency of nutrient digestion, particularly when taking into account that the glucosinolate content (having especially negative impact on the newborn animals) in conventional RC meal products is very low (16). When rapeseed meal, derived from rapeseed low in glucosinolates and also fiber (so called 'yellow' variety), was used in starter feed, digestion efficiency in calves was not negatively affected despite that its inclusion exceeded $30 \%$ in the starter feed (10). Thus, selection of RC for low fiber content or various processing methods allowing for reducing fiber content in the meal (2) are strategies that may increase the ability to include greater concentrations of RC meal in starter diets for calves, and likely other livestock animals. However, it is possible to include RC meal into starters without a substantial increase in the fiber concentration through more complex formulations of calf starters than just replacing SB protein (5). Furthermore, feed additives stimulating gastrointestinal tract development in calves, such as sodium butyrate (12), can be utilized to enhance digestion efficiency in calves fed starter mixtures containing RC meal; however, results of studies conducted so far seem to suggest that the effect of butyrate does not override the impact of RC meal use in calves when commercially available feed additives (e.g., microencapsulated sodium butyrate) were included in starter mixture (6). This area of calf nutrition requires more research in the future.

\section{Impact on growth and feed efficiency}

As previously stated, $\mathrm{RC}$ meal use in starter diets for calves, in general, reduces feed intake and total tract nutrient digestion which results in reduced gain, feed efficiency, or both. From the available studies, it is clear that a reduction in growth and feed efficiency can be expected especially when rapeseed meal high in glucosinolates is used in the feed $(21,37)$. However, independent to glucosinolate concentration in the starter, inclusion of $\mathrm{RC}$ meal in the starter at concentrations greater than 20 to $25 \%$, or when RC meal replaces over 50 to $60 \%$ of the protein coming from SB meal also reduces gain and feed efficiency $(14,25,38)$. Interestingly, the negative impact on feed efficiency seems to be easier to detect as in numerous studies, average daily gain did not differ among treatments while feed efficiency was less when calves were fed starters with $\operatorname{RC}$ meal $(6,25,40)$, or the impact on feed efficiency was much more apparent than on growth of animals $(14,37)$.

Reduced feed efficiency when RC meal is fed to calves can be at least partially attributed to lower digestibility. Past studies have clearly indicated that protein digestion was reduced when RC meal was used in calf starters $(24,37)$. In fact, a more recent study has highlighted that excessive heating may be a partial driver for this response (4); however, it is not expected that such reductions may limit the growth of calves and thus efficiency of nutrient use when inclusion of RC meal does not exceed 20 to $25 \%$. The lack of an effect on growth performance when RC meal inclusion in starter mixture is limited is further supported by results of studies showing reduced intake of protein by calves due to feeding canola meal without an effect on daily gain (33). In turn, high inclusion of RC meal in starter mixtures in most cases results in increased fiber content in the feed $(14,25,43)$, of which digestion efficiency in calves is low, particularly early in life. Although fiber digestion increases with age, this increase is most apparent after weaning $(17,19)$. As a consequence, higher fiber content in the starter diet containing RC meal (and simultaneously lower starch content) should be considered as the most important factor reducing feed efficiency in calves, as this leads to reduced available energy for calves. Furthermore, RC meal is high in lignin, of which digestibility is very limited (42; Table 2 ). To support that, when fiber or starch content in starter mixtures were equalized between treatments, no negative impacts on growth performance and/or feed efficiency were observed $(5,10,37)$. Taking into account that energy intake has a more profound impact on growth of calves than protein intake (18), increasing available energy intake when calf starters contain RC meal (e.g., by ensuring high starch content in starter) is a strategy that may improve ability to use RC meal for young calves. However, it is unlikely to obtain starter low in fiber (or high in starch) when RC meal fully replaces SB meal.

Lower lysine concentration in starter mixture containing $\mathrm{RC}$ meal may be also considered as a factor contributing to lesser efficiency of RC meal feeding to calves. Lysine is considered as one of the most important amino acid limiting calves growth (25). However, depending on other ingredients present in starter mixtures and concentration of lysine in those ingredients, lysine concentration may be similar in starter mixtures containing $\mathrm{RC}$ meal and starter mixtures containing SB meal (Burakowska K., Penner G. B., Korytkowski Ł., Kowalski Z. M., Górka P., unpublished). Furthermore, increasing lysine content in starter diet containing canola 
meal as a main source of protein had no impact on growth performance of calves and feed efficiency (25). Therefore, at least lysine intake with starter mixtures containing $\mathrm{RC}$ rather do not contributes to less efficient use of such starter mixtures.

\section{Conclusions}

In past studies in which rapeseed meal high in glucosinolates were used in calf starters it resulted in reduced feed intake, growth, and nutrient digestibility, especially when rapeseed meal was used as the main source of protein it the starter. However, the rapeseed and canola meal that are currently available are low in glucosinolates. Despite that, their use as the main source of protein in calf starter (i.e. to fully replace SB meal) may still lead to reductions in feed intake, growth performance, and feed efficiency, likely due to the presence of various antinutritional (and unpalatable) factors in RC meal and relatively high fiber content. Nevertheless, inclusion of RC meal in calf starter at less than 20 to $25 \%$ of the feed, or partial replacement of SB protein $(\approx 50$ to $60 \%)$ with $\mathrm{RC}$ meal results in only a minor impact on feed intake, growth performance, and feed efficiency. Besides limiting $\mathrm{RC}$ meal inclusion in starters for calves, potential negative consequences of its use can be minimized by the inclusion of sweet feeds in the starter in order to improve palatability and by formulating starters to ensure enough available energy (i.e. prevent substantial increase in fiber content). Results of studies also suggest that delaying intake of starters containing RC meal, for example, by feeding more liquid feeds to calves may mitigate negative effects. Pelleting of feed also limits potential feed sorting against $\mathrm{RC}$ meal, and thus reduces feed wastage or a reduction in feed efficiency due to unbalanced protein to energy intake.

\section{Financial Support}

This review received no grant from any funding agency or sector.

\section{Ethical Statement}

This study does not present any ethical concerns.

\section{Conflict of Interest}

The authors declared that there is no conflict of interest.

\section{References}

1. Adewole D, Rogiewicz A, Dyck B, et al (2017): Standardized ileal digestible amino acid contents of canola meal from Canadian crushing plants for growing pigs. $\mathrm{J}$ Anim Sci, 95, 2670-2679.

2. Bach Knudsen KE (2018): Alternative Feed Ingredients and Technologies for Improved Nutritive Value of Feed. EuroTier 2018, Hanover, Germany.
3. Bell JM (1984): Nutrients and toxicants in rapeseed meal: a review. J Anim Sci, 58, 996-1010.

4. Burakowska K, Górka P, Kowalski ZM, et al (2016): Effect of Canola Meal Heat Treatment and Glycerol Inclusion in Calf Starter on GIT Development. 81-82. In: Proceedings of $5^{\text {th }}$ EAAP, International Symposium on Energy and Protein Metabolism and Nutrition. Wageningen Academic Pulishers, Krakow, Poland.

5. Burakowska K, Górka P, Penner G (2018): Determination of the optimal canola meal inclusion rate in pelleted starters for Holstein calves. J Anim Sci, 96, 241241.

6. Burakowska K, Przybyło M, Penner GB, et al (2017): Evaluating the effect of protein source and microencapsulated sodium butyrate in starter mixtures on gastrointestinal tract development of dairy calves. J Dairy Sci, 100, 347.

7. Claypool DW, Hoffman CH, Oldfield JE, et al (1985): Canola-meal, cottonseed, and soybean meals as protein supplements for calves. J Dairy Sci, 68, 67-70.

8. Fenwick GR (1982): The assessment of a new protein source-Rapeseed. Proc Nutr Soc, 41, 277-288.

9. Fiems LO, Boucque V, Cottyn BG, et al (1985): Evaluation of rapeseed meal with low and high glucosinolates as a protein source in calf starters. Livest Prod Sci, 12, 131-143.

10. Fisher LJ (1980): A comparison of rapeseed meal and soybean meal as a source of protein and protected lipid as a source of supplemental energy for calf starter diets. Can J Anim Sci, 60, 359-366.

11. Ginane C, Baumont R, Favreau-Peigné A (2011): Perception and hedonic value of basic tastes in domestic ruminants. Physiol Behav, 104, 666-674.

12. Górka P, Kowalski ZM, Zabielski R, et al (2018): Use of butyrate to promote gastrointestinal tract development in calves. J Dairy Sci, 101, 4785-4800.

13. Guilloteau P, Zabielski R, Blum JW (2009): Gastrointestinal tract and digestion in the young ruminant: ontogenesis, adaptations, consequences and manipulations. J Physiol Pharmacol, 60, 37-46.

14. Hadam D, Kański J, Burakowska K, et al (2016): Effect of canola meal use as a protein source in a starter mixture on feeding behavior and performance of calves during the weaning transition. J Dairy Sci, 99, 1247-1252.

15. Heuzé V, Tran G, Kaushik S (2020): Soybean meal. Feedipedia, a programme by INRA, CIRAD, AFZ and FAO (last updated on March 4, 2020, 18:25). Avaliable at https://www.feedipedia.org/node/674. (Accessed March 10, 2020).

16. Heuzé V, Tran G, Sauvant D, et al (2020): Rapeseed meal. Feedipedia, a programme by INRA, CIRAD, AFZ and FAO (last updated on January 31, 2020, 17:04). Avaliable at https://www.feedipedia.org/node/52. (Accessed March 10, 2020).

17. Hill TM, Bateman HG, II, Aldrich JM, et al (2010): Effect of milk replacer program on digestion of nutrients in dairy calves. J Dairy Sci, 93, 1105-1115.

18. Hill TM, Quigley JD, Bateman HG, II, et al (2016): Source of carbohydrate and metabolizable lysine and methionine in the diet of recently weaned dairy calves on digestion and growth. J Dairy Sci, 99, 2788-2796. 
19. Hill TM, Quigley JD, Bateman HG, II, et al (2016): Effect of milk replacer program on calf performance and digestion of nutrients in dairy calves to 4 months of age. J Dairy Sci, 99, 8103-8110.

20. Huhtanen P, Hetta M, Swensson C (2011): Evaluation of canola meal as a protein supplement for dairy cows: A review and a meta-analysis. Can J Anim Sci, 91, 529-543.

21. Ingalls JR, Seale ME (1971): Effect of continuous feeding of rapeseed meal on growth of dairy calves and subsequent first lactation yield. Can J Anim Sci, 51, 681-686.

22. Ingalls JR, Sharma HR (1975): Feeding of Bronowski, Span and commercial rapeseed meals with or without addition of molasses or flavor in rations of lactating cows. Can J Anim Sci, 55, 721-729.

23. Khan MA, Bach A, Weary DM, et al (2016): Transitioning from milk to solid feed in dairy heifers. J Dairy Sci, 99, 885-902.

24. Khorasani GR, Sauer WC, Ozimek L, et al (1990): Digestion of soybean meal and canola meal protein and amino acids in the digestive tract of young ruminants. $\mathrm{J}$ Anim Sci, 68, 3421-3428.

25. Krupa K (2018): The effect of lysine supplementation in the starter mixture on the effects of rearing of calves. MSC Thesis. Department of Animal Nutrition and Dietetics, University of Agriculture in Krakow, Krakow, Poland.

26. Maison T (2013): Evaluation of the nutritional value of canola meal, 00-rapeseed meal, and 00-rapeseed expellers fed to pigs. PhD Thesis. Graduate College of the University of Illinois at Urbana-Champaign, University of Illinois, Urbana, Il, US.

27. Martineau R, Ouellet DR, Lapierre H (2013): Feeding canola meal to dairy cows: A meta-analysis on lactational responses. J Dairy Sci, 96, 1701-1714.

28. Mawson R, Heaney RK, Zdunczyk Z, et al (1993): Rapeseed meal-glucosinolates and their antinutritional effects. Part 2. Flavour and palatability. Food/Nahrung, 37, 336-344.

29. Meale SJ, Leal LN, Martín-Tereso J, et al (2015): Delayed weaning of Holstein bull calves fed an elevated plane of nutrition impacts feed intake, growth and potential markers of gastrointestinal development. Anim Feed Sci Tech, 209, 268-273.

30. Mejicanos G, Sanjayan N, Kim IH, et al (2016): Recent advances in canola meal utilization in swine nutrition. $\mathrm{J}$ Anim Sci Tech, 58, 7.
31. Micek P, Slota K, Górka P (2020): Effect of heat treatment and heat treatment in combination with lignosulfonate on in situ rumen degradability of canola cake crude protein, lysine and methionine. Can J Anim Sci, 100, 165-174.

32. Miller-Cushon EK, Montoro C, Ipharraguerre IR, et al (2014): Dietary preference in dairy calves for feed ingredients high in energy and protein. J Dairy Sci, 97, 1634-1644.

33. Miller-Cushon EK, Terré M, DeVries TJ, et al (2014): The effect of palatability of protein source on dietary selection in dairy calves. J Dairy Sci, 97, 4444-4454.

34. Montagne L, Toullec R, Savidge T, et al (1999): Morphology and enzyme activities of the small intestine are modulated by dietary protein source in the preruminant calf. Reprod Nutr Dev, 39, 455-466.

35. Nair J, Penner GB, Yu P, et al (2016): Evaluation of canola meal derived from Brassica juncea and Brassica napus on rumen fermentation and nutrient digestibility by feedlot heifers fed finishing diets. Can J Anim Sci, 96, 342-353.

36. Newkirk R (2009): Canola Meal: Feed Industry Guide. $4^{\text {th }}$ Ed. Canadian Int. Grains Inst., Canola Council, Winnipeg, Mannitoba, Canada.

37. Schingoeth DJ, Beardsley GL, Muller LD (1974): Evaluation of commercial rapeseed meal and bronowski variety rapeseed meal in calf rations. J Nutr, 104, 558-562.

38. Stake PE, Owens MJ, Schingoethe DJ (1973): Rapeseed, sunflower, and soybean meal supplementation of calf rations. J Dairy Sci, 56, 783-788.

39. Stone JB, Wood AS (1973): Rapeseed meal as a protein source in the starter concentrate for replacement calves. Can J Anim Sci, 53, 327-332.

40. Terre M, Devant M, Bach A (2016): The importance of calf sensory and physical preferences for starter concentrates during pre- and postweaning periods. J Dairy Sci, 99, 7133-7142.

41. Tripathi MK, Mishra AS (2007): Glucosinolates in animal nutrition: A review. Anim Feed Sci Tech, 132, 1-27.

42. Van Soest P (1994): Nutritional Ecology of the Ruminant. Cornell University Press, Ithaca, NY, USA.

43. Wheeler EE, Veira DM, Stone JB (1980): Comparison of tower rapeseed meal and soybean meal as sources of protein in pelleted calf starter rations. Can J Anim Sci, 60, 93-97.

44. Wood A, Stone J (1970): Digestibility, nitrogen retention and caloric value of rapeseed and soybean meals when fed at two dietary levels to calves. Can J Anim Sci, 50, 507-512. 